\title{
A Review of Onychomycosis Due to Aspergillus Species
}

\author{
Felix Bongomin $\cdot$ C. R. Batac $\cdot$ Malcolm D. Richardson $\cdot$ David W. Denning $\mathbb{B}$
}

Received: 21 August 2017/Accepted: 2 November 2017/Published online: 16 November 2017

(C) The Author(s) 2017. This article is an open access publication

\begin{abstract}
Aspergillus spp. are emerging causative agents of non-dermatophyte mould onychomycosis (NDMO). New Aspergillus spp. have recently been described to cause nail infections. The following criteria are required to diagnose onychomycosis due to Aspergillus spp.: (1) positive direct microscopy and (2) repeated culture or molecular detection of Aspergillus spp., provided no dermatophyte was isolated. A review of 42 epidemiological studies showed that onychomycosis due to Aspergillus spp. varies between $<1$ and $35 \%$ of all cases of
\end{abstract}

F. Bongomin - M. D. Richardson · D. W. Denning The National Aspergillosis Centre, Education and Research Centre, Wythenshawe Hospital, Manchester University NHS Foundation Trust, Southmoor Road, Manchester M23 9LT, UK

C. R. Batac

Skin Study Group, Institute of Herbal Medicine, National Institutes of Health, University of the Philippines -

Manila, Manila, Philippines

M. D. Richardson

NHS Mycology Reference Centre, Wythenshawe Hospital, Manchester University NHS Foundation Trust, Southmoor Road, Manchester M23 9LT, UK

F. Bongomin · D. W. Denning $(\bowtie)$

Division of Infection, Immunity and Respiratory Medicine, School of Biological Sciences, Faculty of Biology, Medicine and Health, The University of Manchester, Oxford Road, Manchester M13 9PL, UK e-mail: ddenning@manchester.ac.uk onychomycosis in the general population and higher among diabetic populations accounting for up to $71 \%$ and the elderly; it is very uncommon among children and adolescence. Aspergillus spp. constitutes $7.7-100 \%$ of the proportion of NDMO. The toenails are involved 25 times more frequently than fingernails. A. flavus, A. terreus and A. niger are the most common aetiologic species; other rare and emerging species described include A. tubingensis, A. sydowii, A. alliaceus, A. candidus, A. versicolor, A. unguis, A. persii, A. sclerotiorum, A. uvarum, A. melleus, A. tamarii and $A$. nomius. The clinical presentation of onychomycosis due to Aspergillus spp. is non-specific but commonly distal-lateral pattern of onychomycosis. A negative culture with a positive $\mathrm{KOH}$ may point to a NDM including Aspergillus spp., as the causative agent of onychomycosis. Treatment consists of systemic therapy with terbinafine or itraconazole.

Keywords Aspergillus - Onychomycosis - Clinical features $\cdot$ Epidemiology $\cdot$ Mycology
Abbreviations
DLSO Distal-lateral subungual onychomycosis
EO Endonyx onychomycosis
$\mathrm{KOH}$ Potassium hydroxide
MPO Mixed pattern onychomycosis
NDM Non-dermatophyte mould
NDMO Non-dermatophyte mould onychomycosis
PSO Proximal subungual onychomycosis 
SWO Superficial white onychomycosis

TDO Total dystrophic onychomycosis

\section{Introduction}

Onychomycosis are caused by dermatophytes, nondermatophyte (saprophytic) moulds (NDMs) or yeasts. Aspergillus spp., Scopulariopsis spp., Alternaria spp., Acremonium spp. and Fusarium spp. are the most common NDM agents reported to be responsible for approximately $2-25 \%$ of all the causes of onychomycoses [1-3]. NDM onychomycosis presents with clinical features mimicking dermatophytic onychomycosis, making clinical diagnosis difficult and unreliable [4]. Very little is known regarding the ability of NDM to invade an intact nail plate. [5]

Aspergillus spp. are increasingly being reported as primary causative agents of onychomycosis worldwide with prevalence as high as $34.4 \%$ in Guatemala [6], 69.3\% in Iran [4] and up to $71 \%$ among diabetic patients in Sri Lanka [7]. It has been previously thought that same species of Aspergillus were responsible for both superficial (e.g. onychomycosis) and systemic infections; however, many new species of Aspergillus are increasingly being reported to cause onychomycosis and these were not previously reported to cause systemic infections [8, 9].

The isolation of Aspergillus spp. from nail specimens may mean several things: causative agent, coloniser or contaminant. Aspergillus spp. isolated from nail specimens are not susceptible to most of the topical and systemic antifungals used to treat dermatophytes [2]. Resistance to triazole antifungals occurs among the Aspergilli [10] and inadequate treatment may lead to resistance and recurrence of infection. Proper clinical diagnosis, laboratory workup and adequate antifungal therapy are thus the standard of care for Aspergillus infections.

The prevalence, clinical manifestations and mycological characteristics of onychomycosis caused by Aspergillus spp. are poorly understood. This review evaluates the clinicomycological characteristics and epidemiology of onychomycosis due to Aspergillus. We use the species name to describe both that species and closely related, often cryptic species, for the commonest species complex.
Epidemiology of Onychomycosis due to Aspergillus Species

Onychomycosis is a common condition accounting for up to $18-50 \%$ of all nail diseases and $30 \%$ of cutaneous fungal infections [11]. The global burden of fungal nail, skin and hair infections is about 1 billion cases [12], translating to nearly 300 million cases of onychomycosis globally. Aspergillus species accounts for $0.5-3 \%$ of all cases of onychomycosis [13]; therefore, about 10 million cases of onychomycosis are attributable to Aspergillus spp.

We reviewed data from 42 epidemiological studies from 19 countries across the globe between 1974 and 2017. The prevalence of onychomycosis due to Aspergillus spp., both as percentage of all causes of onychomycosis and as percentage of NDM, shows a marked geographical variation among countries, different regions of same country, over time in the same region and underlying co-morbid conditions or occupational predisposition (Table 1). As an overall cause of onychomycosis, the prevalence of onychomycosis due to Aspergillus spp. varies between $<1$ and $35 \%$ in the general population and higher among diabetic populations at $71 \%$ (Table 1). Aspergillus spp. constitutes $7.7-100 \%$ of the proportion of NDM onychomycosis. Over $50 \%(23 / 42)$ of the reviewed epidemiological studies reportedly isolated Aspergillus spp. in 50-100\% of the NDMs. Onychomycosis due to Aspergillus spp. is thus more prevalent and emerging cause of onychomycosis than previously thought.

Generally, A. niger (complex) and A. flavus (complex) are the commonest species group of Aspergillus isolated from abnormal nail specimens. A. fumigatus, A. terreus and A. nidulans are also common, as reported from the epidemiological studies (Table 1). Rare and newly described species from case reports include A. tubingensis, A. sydowii, A. alliaceus, A. candidus, A. versicolor, A. unguis, A. persii, A. sclerotiorum, A. uvarum, A. melleus, A. tamarii, A. nomius and others, some of which are with the main pathogenic species complexes [9, 14].

\section{Predisposing Factors}

Factors such as increasing age, nail trauma, immunodeficiency, hyperhidrosis, socio-economic status, 
Table 1 Prevalence of Aspergillus onychomycosis

\begin{tabular}{|c|c|c|c|c|c|c|c|}
\hline $\begin{array}{l}\text { Author/ } \\
\text { references }\end{array}$ & Year & Country & $\begin{array}{l}\text { Number } \\
\text { of } \\
\text { cases* }\end{array}$ & $\begin{array}{l}\% \text { of total } \\
\text { cause of } \\
\text { onychomycosis }\end{array}$ & $\begin{array}{l}\% \text { of total } \\
\text { non- } \\
\text { dermatophyte }\end{array}$ & $\begin{array}{l}\text { Most common } \\
\text { Aspergillus species }\end{array}$ & Comments \\
\hline $\begin{array}{l}\text { Moubasher } \\
\text { et al. [38] }\end{array}$ & 2017 & Assiut, Egypt & 125 & 15.9 & 19.5 & $\begin{array}{l}\text { A. niger, A. flavus and } \\
\text { A. terreus }\end{array}$ & - \\
\hline $\begin{array}{l}\text { Martínez- } \\
\text { Herrera et al. } \\
\text { [6] }\end{array}$ & 2016 & Guatemala & 32 & - & 34.4 & Not stated & $\begin{array}{l}\text { Opportunistic } \\
\text { mould } \\
\text { onychomycosis }\end{array}$ \\
\hline $\begin{array}{l}\text { Motamedi et al. } \\
\text { [4] }\end{array}$ & 2016 & Tehran, Iran & 424 & 12.3 & 69.3 & A. flavus & \\
\hline $\begin{array}{l}\text { Chadeganipour } \\
\text { et al. [39] }\end{array}$ & 2016 & Isfahan, Iran & 1,284 & 9.1 & 62.2 & A. flavus $(66 \%)$ & $\begin{array}{l}\text { A. nidulans }(16 \%) \text {, } \\
\text { A. fumigatus } \\
(10 \%) \text { A. terreus } \\
(8 \%)\end{array}$ \\
\hline $\begin{array}{l}\text { Wijesuriya } \\
\text { et al. [7] }\end{array}$ & 2015 & Sri Lanka & 255 & 71.0 & 100 & A. niger $(76 \%)$ & $\begin{array}{l}\text { Diabetic } \\
\text { populations }\end{array}$ \\
\hline $\begin{array}{l}\text { Nouripour- } \\
\text { Sisakht et al. } \\
{[14]}\end{array}$ & 2015 & Tehran, Iran & 463 & 29.2 & 87.7 & A. flavus $(77.3 \%)$ & $\begin{array}{l}\text { A. niger }(3 \%), \text { A. } \\
\text { tubingensis }(3 \%), \\
\text { A. terreus }(2.2 \%) \text {, } \\
\text { A. sydowii }(2.2 \%)\end{array}$ \\
\hline $\begin{array}{l}\text { Raghavendra } \\
\text { et al. [28] }\end{array}$ & 2015 & $\begin{array}{l}\text { Rajasthan, } \\
\text { India }\end{array}$ & 150 & 30.0 & 84.9 & A. flavus $(53.3 \%)$ & $\begin{array}{l}\text { A. niger }(33.3) \text { and } \\
\text { A. fumigatus } \\
(13.3 \%)\end{array}$ \\
\hline $\begin{array}{l}\text { Soltani et al. } \\
\text { [20] }\end{array}$ & 2015 & Tehran, Iran & 79 & - & 50 & Not stated & - \\
\hline $\begin{array}{l}\text { Afshar et al. } \\
\text { [40] }\end{array}$ & 2014 & $\begin{array}{l}\text { Mazandaran, } \\
\text { Iran }\end{array}$ & 625 & 14.2 & 89.3 & A. flavus $(67 \%)$ & Toe and finger nails \\
\hline $\begin{array}{l}\text { Shahzad et al. } \\
\text { [26] }\end{array}$ & 2014 & $\begin{array}{l}\text { Qassim, } \\
\text { Saudi } \\
\text { Arabia }\end{array}$ & 77 & 29.9 & 82.1 & Not stated & - \\
\hline $\begin{array}{l}\text { Morales- } \\
\text { Cardona et al. } \\
{[41]}\end{array}$ & 2014 & $\begin{array}{l}\text { Bogota, } \\
\text { Colombia }\end{array}$ & 317 & - & 2.6 & Not stated & \\
\hline $\begin{array}{l}\text { Mikaeili et al. } \\
\text { [42] }\end{array}$ & 2013 & $\begin{array}{l}\text { Kermanshah, } \\
\text { Iran }\end{array}$ & 1086 & 2.2 & 75.0 & A. flavus (50\%), & $\begin{array}{l}\text { A. niger }(33 \%), \text { A. } \\
\text { fumigatus }(17 \%)\end{array}$ \\
\hline $\begin{array}{l}\text { Vasconcellos } \\
\text { et al. [43] }\end{array}$ & 2013 & $\begin{array}{l}\text { Sao Paolo, } \\
\text { Brazil }\end{array}$ & 35 & 5.6 & 33.3 & Not stated & $\begin{array}{l}\text { Institutionalised } \\
\text { elderly patients }\end{array}$ \\
\hline Dhib et al. [44] & 2012 & $\begin{array}{l}\text { Central, } \\
\text { Tunisia }\end{array}$ & 5789 & 1.1 & 42.7 & $\begin{array}{l}\text { A. flavus }(44.3 \%), A . \\
\quad \text { niger }(18 \%)\end{array}$ & $\begin{array}{l}\text { A } 22 \text {-year } \\
\text { retrospective } \\
\text { study }\end{array}$ \\
\hline $\begin{array}{l}\text { Hajoui et al. } \\
\text { [32] }\end{array}$ & 2012 & Morocco & 150 & - & 35.3 & Not stated & $\begin{array}{l}\text { 20-year } \\
\text { retrospective } \\
\text { study on only } \\
\text { mould } \\
\text { onychomycosis }\end{array}$ \\
\hline $\begin{array}{l}\text { Leelavathi et al. } \\
\text { [45] }\end{array}$ & 2012 & Malaysia & 231 & 35.1 & 59.8 & Not stated & $\begin{array}{l}\text { 5-year retrospective } \\
\text { study }\end{array}$ \\
\hline $\begin{array}{l}\text { Minkoumou } \\
\text { et al. [46] }\end{array}$ & 2012 & Cameroon & 52 & 13.5 & 70.0 & A. niger $(71 \%)$ & $\begin{array}{l}\text { A. unguis }(14 \%), A . \\
\text { alliaceus }(14 \%)\end{array}$ \\
\hline $\begin{array}{l}\text { Ranawaka et al. } \\
\text { [47] }\end{array}$ & 2012 & $\begin{array}{l}\text { Galle, Sri } \\
\text { lanka }\end{array}$ & 128 & 30.6 & 66.7 & A. niger $(73.1 \%)$, & $\begin{array}{l}\text { A. flavus }(19.2 \%) \text {, } \\
\text { A. terreus }(7.7 \%)\end{array}$ \\
\hline $\begin{array}{r}\text { Aghamirian } \\
\text { et al. [48] }\end{array}$ & 2010 & Qazvin, Iran & 124 & 3.2 & 100 & $\begin{array}{l}\text { A. niger and A. flavus } \\
\text { (50\% each) }\end{array}$ & $\begin{array}{l}\text { All-cause: No other } \\
\text { NDM isolated }\end{array}$ \\
\hline
\end{tabular}


Table 1 continued

\begin{tabular}{|c|c|c|c|c|c|c|c|}
\hline $\begin{array}{l}\text { Author/ } \\
\text { references }\end{array}$ & Year & Country & $\begin{array}{l}\text { Number } \\
\text { of } \\
\text { cases* }\end{array}$ & $\begin{array}{l}\% \text { of total } \\
\text { cause of } \\
\text { onychomycosis }\end{array}$ & $\begin{array}{l}\% \text { of total } \\
\text { non- } \\
\text { dermatophyte }\end{array}$ & $\begin{array}{l}\text { Most common } \\
\text { Aspergillus species }\end{array}$ & Comments \\
\hline $\begin{array}{l}\text { Bassiri-Jahromi } \\
\text { et al. [30] }\end{array}$ & 2010 & Tehran, Iran & 410 & 6.8 & 59.6 & A. fumigatus $(27.6 \%)$ & - \\
\hline $\begin{array}{l}\text { Souza et al. } \\
\text { [49] }\end{array}$ & 2010 & $\begin{array}{c}\text { Goiania, } \\
\text { Brazil }\end{array}$ & 1282 & 0.08 & 50 & Not stated & $\begin{array}{l}\text { Only } 1 \text { patient had } \\
\text { Aspergillus isolate }\end{array}$ \\
\hline $\begin{array}{l}\text { Adhikari et al. } \\
\text { [50] }\end{array}$ & 2009 & Sikkim, India & 32 & 21.43 & 60 & A. niger $(100 \%)$ & - \\
\hline $\begin{array}{l}\text { Godoy et al. } \\
\text { [51] }\end{array}$ & 2009 & $\begin{array}{l}\text { Sao Paolo, } \\
\text { Brazil }\end{array}$ & 247 & 0.6 & 7.7 & Not stated & - \\
\hline $\begin{array}{l}\text { Hashemi et al. } \\
\text { [52] }\end{array}$ & 2009 & Tehran, Iran & 216 & 9.7 & 51.2 & A. flavus (43\%) & $\begin{array}{l}\text { A. niger }(19 \%), A . \\
\text { fumigatus }(14 \%) \text {. }\end{array}$ \\
\hline $\begin{array}{l}\text { Chadeganipour } \\
\text { et al. [53] }\end{array}$ & 2008 & Isfahan, Iran & 185 & 22.2 & 77.4 & A. flavus (59\%), & $\begin{array}{l}\text { A. nidulans }(12 \%) \text {, } \\
\text { A. fumigatus }(7.3)\end{array}$ \\
\hline Das et al. [54] & 2008 & Eastern, India & 44 & 18.2 & 80.0 & A niger $(100 \%)$ & $\begin{array}{l}\text { Finger nail } \\
\text { onychomycoses }\end{array}$ \\
\hline $\begin{array}{l}\text { Manzano- } \\
\text { Gayosso et al. }\end{array}$ & 2008 & Mexico & 70 & 1.4 & 16.7 & A. fumigatus $(100 \%)$ & $\begin{array}{l}\text { Type } 2 \text { diabetes } \\
\text { mellitus patients }\end{array}$ \\
\hline $\begin{array}{l}\text { Surjushe et al. } \\
\text { [55] }\end{array}$ & 2007 & $\begin{array}{l}\text { Mumbai, } \\
\text { India }\end{array}$ & 60 & 5.0 & 15.8 & A. niger $(100 \%)$ & $\begin{array}{l}\text { HIV-infected } \\
\text { persons }\end{array}$ \\
\hline Veer et al. [56] & 2007 & India & 72 & 14 & 50.0 & Not stated & $\begin{array}{l}\text { Of the non- } \\
\text { dermatophyte } \\
\text { moulds }\end{array}$ \\
\hline $\begin{array}{l}\text { Gupta et al. } \\
\text { [19] }\end{array}$ & 2007 & $\begin{array}{l}\text { Himachal } \\
\text { Pradesh, } \\
\text { India }\end{array}$ & 130 & 6.1 & 33.3 & Not stated & - \\
\hline $\begin{array}{l}\text { Bonifaz et al. } \\
\text { [57] }\end{array}$ & 2007 & Mexico & 5221 & 0.51 & 34.6 & A. niger & $\begin{array}{l}\text { Retrospective study } \\
\text { 1992-2005 }\end{array}$ \\
\hline $\begin{array}{l}\text { Hilmioglu- } \\
\text { Polat et al. } \\
\text { [58] }\end{array}$ & 2005 & Izmir, Turkey & 1,146 & 1.5 & 30.3 & A. niger $(70 \%)$ & $\begin{array}{l}\text { A. flavus }(10 \%), \text { A. } \\
\text { fumigatus }(10 \%) \text {, } \\
\text { A. terreus }(10 \%)\end{array}$ \\
\hline $\begin{array}{l}\text { Boukachabine } \\
\text { et al. [59] }\end{array}$ & 2005 & Morocco & - & - & 12.0 & - & $\begin{array}{l}\text { 22-year } \\
\text { (1982-2003) } \\
\text { retrospective } \\
\text { study. }\end{array}$ \\
\hline $\begin{array}{l}\text { Romano et al. } \\
\text { [21] }\end{array}$ & 2005 & Italy & 46 & 2.2 & 33.3 & A. fumigatus (100\%) & In children \\
\hline $\begin{array}{l}\text { Gianni and } \\
\text { Romano [27] }\end{array}$ & 2004 & Italy & 1,228 & 2.6 & 47.9 & A. fumigatus (29\%) & $\begin{array}{l}\text { A. niger }(21 \%), A . \\
\text { terreus }(12 \%)\end{array}$ \\
\hline $\begin{array}{l}\text { Piraccini et al. } \\
{[60]}\end{array}$ & 2004 & Italy & 79 & 6 & 29.4 & Not stated & $\begin{array}{l}\text { Cases of white } \\
\text { superficial } \\
\text { onychomycosis }\end{array}$ \\
\hline $\begin{array}{l}\text { Grover et al. } \\
\text { [33] }\end{array}$ & 2003 & $\begin{array}{l}\text { Bangalore } \\
\text { and Jorhat, } \\
\text { India }\end{array}$ & 50 & 18.6 & 84.6 & A. niger $(100 \%)$ & - \\
\hline $\begin{array}{l}\text { Romano et al. } \\
\text { [61] }\end{array}$ & 2003 & Italy & 4,046 & 3.3 & 25.2 & Not stated & 15 -year survey \\
\hline $\begin{array}{l}\text { Bokhari et al. } \\
\text { [62] }\end{array}$ & 1999 & $\begin{array}{l}\text { Lahore, } \\
\text { Pakistan }\end{array}$ & 100 & 2 & 18.2 & Not stated & \\
\hline $\begin{array}{l}\text { Ramani et al. } \\
\text { [63] }\end{array}$ & 1993 & $\begin{array}{l}\text { Karnataka, } \\
\text { India }\end{array}$ & 100 & 19 & 86.4 & A. niger $(36.8 \%)$ & $\begin{array}{l}\text { A. fumigatus } \\
\quad(31.6 \%) \text {, A. flavus } \\
(15.8 \%)\end{array}$ \\
\hline
\end{tabular}


Table 1 continued

\begin{tabular}{|c|c|c|c|c|c|c|c|}
\hline $\begin{array}{l}\text { Author/ } \\
\text { references }\end{array}$ & Year & Country & $\begin{array}{l}\text { Number } \\
\text { of } \\
\text { cases* }\end{array}$ & $\begin{array}{l}\% \text { of total } \\
\text { cause of } \\
\text { onychomycosis }\end{array}$ & $\begin{array}{l}\% \text { of total } \\
\text { non- } \\
\text { dermatophyte }\end{array}$ & $\begin{array}{l}\text { Most common } \\
\text { Aspergillus species }\end{array}$ & Comments \\
\hline Lim et al. [64] & 1992 & Singapore & 100 & 3.0 & 25.0 & Not stated & - \\
\hline $\begin{array}{l}\text { English and } \\
\text { Atkinson [3] }\end{array}$ & 1974 & Bristol, UK & 216 & & 75.0 & $\begin{array}{l}\text { A. terreus }(53 \%), A . \\
\text { versicolor }(40 \%), \\
\text { A. nidulans and } A . \\
\text { candidus }(3 \% \text { each) }\end{array}$ & $\begin{array}{l}\text { Elderly chiropody } \\
\text { patients }\end{array}$ \\
\hline
\end{tabular}

*This refers to the number of onychomycosis cases investigated in the study, regardless of cause

poor hygiene, climatic conditions, occupational exposures such as gardening and house chores, barefoot walking and paronychia predispose to onychomycosis [15]. Furthermore, damage can also be induced by hormonal disturbances (diabetes mellitus, Cushing's syndrome and hypothyroidism) or by HIV/AIDS immunosuppression or ongoing biological (immunosuppressive) therapies [16]. Among diabetics with onychomycosis in Sri Lanka, onychomycosis due to Aspergillus spp. occurred in $71 \%$, among which $A$. niger $(76 \%)$ and A. flavus (12\%) were the most predominant species isolated [7]. The same study showed that the risk of having Aspergillus onychomycosis among diabetics increased with age and duration of diabetes.

None of the above predisposing factors is specific for Aspergillus spp. However, Aspergillus onychomycosis is seen more among individuals with occupational exposures such as vegetable vendors [17] and among babassu coconut breakers [18], diabetics and the elderly [19]. Some individuals diagnosed with onychomycosis due to Aspergillus spp. do not have identifiable predisposing conditions/occupational risk factors. In fact, Soltani and colleagues in their study reported that up to $70 \%$ of patients with Aspergillus onychomycosis had no predisposing conditions [20]. Onychomycosis due to Aspergillus spp. is very uncommon in children. [21, 22]

\section{Pathophysiology}

Aspergillus spp. are ubiquitous environmental moulds found in soil, decaying vegetation and water and are not transmitted from person to person [23]. Infection starts under the nail near the hyponychium where spores may have lodged or at the lateral nail folds, or on a diseased nail plate colonised by Aspergillus spp. [24]. Once the fungus starts to grow, the infection spreads back towards the cuticle. It looks much the same as any fungal nail infection, discolouring the nail, causing it to become thick, distorted and flaky [25]. An early experimental study with $A$. versicolor using healthy nail samples showed that $A$. versicolor could only grow on the surface of the nail without penetrating the nail plate [5]. An evidence of the nonkeratinolytic potentials of these moulds. Aspergillus species growing in nature often produces colourful pigments; therefore, an Aspergillus nail infection may well appear greenish, black, brown or various other shades [17]. The fungus will not, however, spread to the surrounding skin like some other fungal causes of nail infection [17].

\section{Clinical Manifestation}

Onychomycosis due to Aspergillus spp. is usually a distal-lateral subungual onychomycosis (DLSO). The toenails are involved 25 times more frequently than fingernails due to increased exposure to soil, water and decaying vegetation where Aspergillus moulds thrive [17].

Few studies have been carried out correlating the clinical classification with the causative fungal species. One of such studies from Saudi Arabia showed that 17 of the 23 (74\%) cases of onychomycosis due to Aspergillus spp. were DLSO, 5/23 (22\%) 
were proximal subungual onychomycosis (PSO), 2/23 (9\%) were superficial white onychomycosis (SWO) and $1 / 23(4 \%)$ was total dystrophic onychomycosis (TDO) [26]. In a systemic review of NDM onychomycosis, Gupta and colleagues reported that Aspergillus spp. manifest as PSO in $37.5 \%$ of the cases, DLSO in $26.1 \%$ and SWO in $25.5 \%$ [2]. A study in Italy showed that the clinical features suggesting onychomycosis due to Aspergillus spp. are (1) chalky deep white nail, (2) rapid involvement of lamina and (3) painful perionyxis without pus [27]. The clinical pattern, however, appears to vary depending on the Aspergillus species implicated. Raghavendra and colleagues in India described A. flavus causing $19.2 \%$ of DLSO, $18.8 \%$ of TDO and $9.1 \%$ SWO. In contrast, A. niger was associated with $11.5 \%$ of DLSO, $10.1 \%$ of TDO, $9.1 \%$ of SWO and $6.3 \%$ of mixed pattern onychomycosis (MPO), whereas A. fumigatus was associated with DLSO in $2 \%$ of the patients, $5.8 \%$ TDO and $6.3 \%$ MPO [28]. In A. terreus onychomycosis (Fig. 1), the observed clinical patterns in fingernail were DLSO (33.3\%), SWO (33.3\%) and onycholysis (33.3\%), and in toenail, SWO $(52.9 \%)$ was the most frequent clinical pattern followed by DLSO $(42.0 \%)$ and DLSO plus SWO (5.9\%) [29]. Another study showed that among those with onychomycosis due to Aspergillus spp., $93 \%$ manifested with hard nails, $89 \%$ with brittle nails and $85 \%$ had discoloured nails. Involvement of

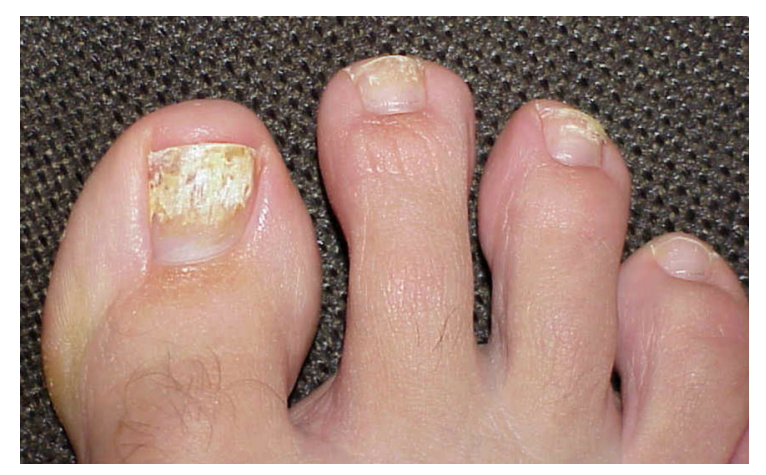

Fig. 1 Distal-lateral subungual onychomycosis caused by Aspergillus terreus in a 60 -year-old immunocompetent man. A flaky, whitish, sharply demarcated patch surrounded by a yellowish discoloration is noted on the distal $2 / 3$ of the first toenail. Similar lesions are noted on the second and third toenails. The first toenail shows signs of paronychia with beginning erythema and swelling of the distal and lateral nail folds. Note the SWO component especially on the first toenail (Courtesy of Prof. David W. Denning, the National Aspergillosis Centre, Manchester, UK) surrounding skin is not common [17]. Subungual hyperkeratosis is almost always present in all patients with mould onychomycosis regardless of the genus of the fungi isolated [30]. Onychomycosis due to Aspergillus spp. are sometimes associated with subungual dermatophytoma ("fungal ball") formation. [6]

\section{Diagnosis}

NDM onychomycosis and therefore onychomycosis due to Aspergillus spp. may be considered in patients with fungal infection in a diseased or traumatised nail, without associated skin involvement, unresponsive to commonly used antifungal agents [31]. It may be suspected in cases which were $\mathrm{KOH}$ positive and culture negative for dermatophytes [31].

The differential diagnoses for onychomycosis due to Aspergillus spp. are very broad and include yeast nail infections, tinea unguium, non-Aspergillus spp. NDMO and other non-fungal nail infections and disorders. Therefore, the diagnosis of onychomycosis due to Aspergillus spp. is both clinical and mycological. Since there are no specific signs associated with onychomycosis due to Aspergillus spp., it is not possible to diagnose it based solely on physical appearance.

Determining the mycological cause of onychomycosis is helpful in guiding antifungal treatment and preventing complications [32]. Identification of the fungal agent directs the treatment plan, as well as prognosis. Since culture of NDMs from nail specimens does not always translate to causation, Gupta et al. [2] proposed that at least 3 of the following criteria should be satisfied: (1) $\mathrm{KOH}$ positive, (2) culture of NDM, (3) repeated culture (2-3) of NDMs, provided no dermatophyte was isolated, (4) histopathology using periodic acid-Schiff staining positive for fungal elements, (5) culture of NDM from 5 of 20 nail inoculated nail fragments and (6) NDM identification through molecular techniques. However, a positive direct microscopy, and repeated culture or molecular detection of Aspergillus spp., provided no dermatophyte was isolated is sufficient to diagnose Aspergillus onychomycosis. Aspergillary heads may be observed with direct microscopic examination of nail specimens, especially in very chronic cases or with onycholysis. [1] 
Mycological culture on Sabouraud's dextrose agar with or without cycloheximide yields fungal isolates in less than $50 \%$ of the cases. However, combining $\mathrm{KOH}$ preparation and culture, sensitivity is increased to $85.8 \%$. [33] Isolation rate is higher (83\%) for nail samples obtained by drilling compared to scraping (67\%) [34].

\section{Treatment}

Treatment options for NDM onychomycosis are still limited; however, onychomycosis caused by Aspergillus spp. responds well to systemic antifungal agents, with itraconazole performing better than terbinafine in vitro [31]. Affected fingernails typically require 3-month therapy and toenails at least 6 months. Terbinafine given as pulse $(500 \mathrm{mg}$ per day for 1 week every month for 3 months) produced complete cure in 30 of 34 cases on the 12-month follow-up [2]. Tosti et al. recommend either daily terbinafine (250 mg per day) or pulse itraconazole (400 mg per day for 1 week per month) for 2-4 months, completely curing 5 of 5 patients with Aspergillus onychomycosis who accepted treatment [35]. Interestingly, the nail discolorations in Aspergillus onychomycosis often persist despite evidence of mycological cure [17]. Systemic antifungals are best combined with chemical nail avulsion using $40 \%$ urea ointment for hyperkeratotic nails and topical ciclopirox olamine nail lacquers for SWO [13]. Terbinafine resistance has been reported with $A$. candidus onychomycosis, and mycological cure was achieved following 10 weeks of itraconazole therapy [36]. Total nail avulsion followed by topical antifungal post-operatively has also been shown to be an effective management option (clinical cure rate $88 \%$ and mycological cure rate 100\%) for patients with single or oligo-onychomycosis [37]. However, it should be noted that comparative clinical trials on the treatment of Aspergillus onychomycosis have not been done to date and that recommendations have been based on case studies.

\section{Conclusion}

Onychomycosis due to Aspergillus spp. is more prevalent and emerging cause of onychomycosis than previously thought. The prevalence ranges from 7.7 to $100 \%$ of all NDMO and between $<1$ and $35 \%$ in the general population. Since the clinical presentation of onychomycosis due to Aspergillus spp. is non-specific, it is necessary to perform laboratory procedures such as $\mathrm{KOH}$, culture, histopathology and molecular techniques to diagnose it. A positive direct microscopy, and repeated culture or molecular detection of Aspergillus spp., provided no dermatophyte was isolated is the required criteria for the diagnosis of onychomycosis due to Aspergillus spp. Treatment consists of systemic therapy with terbinafine or itraconazole.

Funding Global Action Fund for Fungal Infections (GAFFI) supports Felix Bongomin.

\section{Compliance with Ethical Standards}

Conflict of interest Dr. Denning and family hold Founder shares in F2G Ltd, a University of Manchester spin-out antifungal discovery company. He acts or has recently acted as a consultant to Astellas, Sigma Tau, Basilea, Scynexis, Cidara, Biosergen, Quintiles, Pulmatrix, Pulmocide and Zambon. In the last 3 years, he has been paid for talks on behalf of Astellas, Dynamiker, Gilead, Merck and Pfizer. He is a long-standing member of the Infectious Disease Society of America Aspergillosis Guidelines group, the European Society for Clinical Microbiology and Infectious Diseases Aspergillosis Guidelines group and the British Society for Medical Mycology Standards of Care committee. FB, CRB and MDR reports no conflicts of interest.

Open Access This article is distributed under the terms of the Creative Commons Attribution 4.0 International License (http:// creativecommons.org/licenses/by/4.0/), which permits unrestricted use, distribution, and reproduction in any medium, provided you give appropriate credit to the original author(s) and the source, provide a link to the Creative Commons license, and indicate if changes were made.

\section{References}

1. Moreno G, Arenas R. Other fungi causing onychomycosis. Clin Dermatol. 2010;28:160-3. https://doi.org/10.1016/j. clindermatol.2009.12.009.

2. Gupta AK, Drummond-Main C, Cooper EA, Brintnell W, Piraccini BM, Tosti A. Systematic review of nondermatophyte mold onychomycosis: diagnosis, clinical types, epidemiology, and treatment. J Am Acad Dermatol. 2012;66:494-502. https://doi.org/10.1016/j.jaad.2011.02. 038.

3. English MP, Atkinson R. Onychomycosis in elderly chiropody patients. Br J Dermatol. 1974;91:67-72.

4. Motamedi M, Ghasemi Z, Shidfar MR, Hosseinpour L, Khodadadi H, Zomorodian K, et al. Growing incidence of 
non-dermatophyte onychomycosis in Tehran, Iran. Jundishapur J Microbiol. 2016;9:e40543.

5. Richardson M. Effects of lamisil and azole antifungals in experimental nail infection. Dermatology. 1997;194:27-31.

6. Martínez-Herrera EO, Arroyo-Camarena S, Tejada-García DL, Porras-López CF, Arenas R. Onychomycosis due to opportunistic molds. An Bras Dermatol. 2015;90:334-7.

7. Wijesuriya T, Kottahachchi J, Gunasekara TDCP, Bulugahapitiya U, Ranasinghe KNP, Neluka Fernando S, et al. Aspergillus species: An emerging pathogen in onychomycosis among diabetics. Indian $\mathbf{J}$ Endocrinol Metab 2015;19:811. http://www.ijem.in/text.asp?2015/19/6/811/ 167565.

8. Zarei F, Mirhendi H, Fakhim H, Geramishoar M. The first case of onychomycosis due to Aspergillus uvarum (section Nigri). Mycoses. 2015;58:239-42.

9. Zotti M, Agnoletti AF, Vizzini A, Cozzani E, Parodi A. Onychomycosis from Aspergillus melleus, a novel pathogen for humans. Fungal identification and in vitro drug susceptibility. Exp Dermatol. 2015;24:966-8.

10. Bowyer P, Moore CB, Rautemaa R, Denning DW, Richardson MD. Azole antifungal resistance today: focus on Aspergillus. Curr Infect Dis Rep. 2011;13:485-91.

11. Piraccini BM, Sisti A, Tosti A. Long-term follow-up of toenail onychomycosis caused by dermatophytes after successful treatment with systemic antifungal agents. J Am Acad Dermatol. 2010;62:411-4. https://doi.org/10.1016/j. jaad.2009.04.062.

12. Vos T, Flaxman AD, Naghavi M, Lozano R, Michaud C, Ezzati M, et al. Years lived with disability (YLDs) for 1160 sequelae of 289 diseases and injuries 1990-2010: a systematic analysis for the Global Burden of Disease Study 2010. Lancet. 2012;380:2163-96.

13. Negroni R. Onychomycosis due to Aspergillus species. In: Pasqualotto AC, editor. Aspergillosis from diagnosis to prevention. Dordrecht: Springer Netherlands; 2009. p. 961-71.

14. Nouripour-Sisakht S, Mirhendi H, Shidfar MR, Ahmadi B, Rezaei-Matehkolaei A, Geramishoar M, et al. Aspergillus species as emerging causative agents of onychomycosis. J Mycol Med. 2015;25:101-7. https://doi.org/10.1016/j. mycmed.2014.12.001.

15. Summerbell RC, Kane J, Krajden S. Onychomycosis, tinea pedis and tinea manuum Caused by non-dermatophytic filamentous fungi nicht-dermatophyten-fadenpilze als erreger von onychomykosen. Tinea pedis und Tinea manuum. Mycoses. 1989;32:609-19.

16. Ogawa H, Summerbell RC, Clemons KV, Koga T, Ran YP, Rashid A, et al. Dermatophytes and host defence in cutaneous mycoses. Med Mycol. 1998;36(Suppl 1):166-73.

17. Banu A, Anand M, Eswari L. A rare case of onychomycosis in all 10 fingers of an immunocompetent patient. Indian Dermatol Online J. 2013;4:302-4.

18. Nascimento MDSB, Leitao VMS, Silva MACN, Maciel LB, Filho Muniz WE, Viana GMDC, et al. Eco-epidemiologic study of emerging fungi related to the work of babacu coconut breakers in the State of Maranhao, Brazil. Rev Soc Bras Med Trop. 2014;47:74-8.

19. Gupta M, Sharma N, Kanga A, Mahajan V, Tegta G. Onychomycosis: clinico-mycologic study of 130 patients from Himachal Pradesh, India. Indian J Dermatol Venereol
Leprol 2007;73:389. http://www.ijdvl.com/text.asp?2007/ 73/6/389/37055.

20. Soltani M, Khosravi AR, Shokri H, Sharifzadeh A, Balal A. A study of onychomycosis in patients attending a dermatology center in Tehran, Iran. J Mycol Med. 2015;25:e81-7. https://doi.org/10.1016/j.mycmed.2015.03.007.

21. Romano C, Papini M, Ghilardi A, Gianni C. Onychomycosis in children: a survey of 46 cases. Mycoses. 2005;48:430-7.

22. Lange M, Roszkiewicz J, Szczerkowska-Dobosz A, JasielWalikowska E, Bykowska B. Onychomycosis is no longer a rare finding in children. Mycoses. 2006;49:55-9.

23. Kwon-Chung KJ, Sugui JA. Aspergillus fumigatus-What makes the species a ubiquitous human fungal pathogen? PLoS Pathog 2013;9:1-4. http://www.ncbi.nlm.nih.gov/ pubmed/24348239.

24. Moore M, Weiss RS. Onychomycosis caused by Aspergillus Terreus 11 From the dermatological departments of the barnard free skin and cancer hospital and the school of medicine, Washington University, St. Louis, Missouri, Service of Richard S. Weiss, M. D. J Invest Dermatol 1948;11:215-23. http://linkinghub.elsevier.com/retrieve/pii/ S0022202X15503096.

25. Zaias N, Escovar SX, Rebell G. Opportunistic toenail onychomycosis. the fungal colonization of an available nail unit space by non-dermatophytes is produced by the trauma of the closed shoe by an asymmetric gait or other trauma A plausible theory. J Eur Acad Dermatol Venereol. 2014;28:1002-6.

26. Shahzad M, Alzolibani AA, Al Robaee AA, Bin Saif GA, Babikir IHK, Abdel-Magied EM, et al. Onychomycosis in Qassim region of Saudi Arabia: a clinicoaetiologic correlation. J Clin Diagn Res. 2014;8:1-4.

27. Gianni C, Romano C. Clinical and histological aspects of toenail onychomycosis caused by Aspergillus spp.: 34 cases treated with weekly intermittent terbinafine. Dermatology. 2004;209:104-10.

28. Raghavendra K, Yadav D, Kumar A, Sharma M, Bhuria J, Chand A. The nondermatophyte molds: Emerging as leading cause of onychomycosis in south-east Rajasthan. Indian Dermatol Online J 2015;6:92. http://www.idoj.in/text. asp?2015/6/2/92/153010.

29. Fernández MS, Rojas FD, Cattana ME, De Ángeles Sosa M, Mangiaterra ML, Giusiano GE. Aspergillus terreus complex: an emergent opportunistic agent of onychomycosis. Mycoses. 2013;56:477-81.

30. Bassiri-Jahromi S, Khaksar A. Nondermatophytic moulds as a causative agent of onychomycosis in Tehran. Indian $\mathbf{J}$ Dermatol 2010;55:140. http://www.e-ijd.org/text. asp?2010/55/2/140/62743.

31. Ameen M, Lear JT, Madan V, Mohd Mustapa MF, Richardson M. British association of dermatologists' guidelines for the management of onychomycosis 2014. Br J Dermatol. 2014;171:937-58.

32. Hajoui F-ZM, Zeroual Z, Ghfir B, Moustachi A, Lyagoubi $\mathrm{M}$, Aoufi S. The mould onychomycosis in Morocco: about 150 isolated cases in 20 years. $\mathrm{J}$ Mycol Med. 2012;22:221-4.

33. Grover C, Reddy BSN, Chaturvedi KU. Onychomycosis and the diagnostic significance of nail biopsy. J Dermatol. 2003;30:116-22. 
34. Kashyap B, Makkar R, Kaur R. Evaluation of clinicomycological aspects of onychomycosis. Indian $\mathrm{J}$ Dermatol 2008;53:174. http://www.e-ijd.org/text.asp?2008/53/4/174/ 44788.

35. Tosti A, Piraccini BM, Lorenzi S. Onychomycosis caused by nondermatophytic molds: Clinical features and response to treatment of 59 cases. J Am Acad Dermatol 2000;42:217-24. http://linkinghub.elsevier.com/retrieve/ pii/S0190962200701046.

36. Ahmadi B, Hashemi SJ, Zaini F, Shidfar MR, Moazeni M, Mousavi B, et al. A case of onychomycosis caused by Aspergillus candidus. Med Mycol Case Rep. 2012;1:45-8. https://doi.org/10.1016/j.mmcr.2012.06.003.

37. Tsang CC, Hui TWS, Lee KC, Chen JHK, Ngan AHY, Tam EWT, et al. Genetic diversity of Aspergillus species isolated from onychomycosis and Aspergillus hongkongensis sp. nov., with implications to antifungal susceptibility testing. Diagn Microbiol Infect Dis. 2016;84:125-34.

38. Moubasher AH, Abdel-Sater MA, Soliman Z. Incidence and biodiversity of yeasts, dermatophytes and non-dermatophytes in superficial skin infections in Assiut, Egypt. J Mycol Med. 2016;27:166-79. https://doi.org/10.1016/j. mycmed.2017.01.005.

39. Chadeganipour M, Mohammadi R. Causative agents of onychomycosis: a 7-year study. J Clin Lab Anal. 2016;30:1013-20.

40. Afshar P, Khodavaisy S. KSGMRT. Onychomycosis in North-East of Iran. Iran J Microbiol. 2014;6:98-103.

41. Morales-Cardona C, Valbuena-Mesa M, Alvarado Z, Solorzano-Amador A. Non-dermatophyte mould onychomycosis: a clinical and epidemiological study at a dermatology referral centre in Bogota, Colombia. Mycoses. 2014;57:284-93.

42. Mikaeili A, Karimi I. The incidence of onychomycosis infection among patients referred to hospitals in Kermanshah province, Western Iran. Iran J Public Health. 2013;42:320-5.

43. Vasconcellos C, Pereira CQM, Souza MC, Pelegrini A, Freitas RS, Takahashi JP. Identification of fungi species in the onychomycosis of institutionalized elderly. An Bras Dermatol 2013;88:377-80. http://www.scielo.br/scielo. php?script=sci_arttext\&pid=S0365-05962013000300377\& lang=pt.

44. Dhib I, Fathallah A, Yaacoub A, Zemni R, Gaha R, Said MB. Clinical and mycological features of onychomycosis in central Tunisia: a 22 years retrospective study (1986-2007). Mycoses. 2013;56:273-80.

45. Leelavathi M, Tzar MN, Adawiah J. Common microorganisms causing onychomycosis in tropical climate. Sains Malays. 2012;41:697-700.

46. Nkondjo Minkoumou S, Fabrizi V, Papini M. Onychomycosis in Cameroon: a clinical and epidemiological study among dermatological patients. Int $\mathbf{J}$ Dermatol. 2012;51:1474-7.

47. Ranawaka RR, de Silva N, Ragunathan RW. Non-dermatophyte mold onychomycosis in Sri Lanka. Dermatol Online J. 2012;18:7.
48. Aghamirian MR, Ghiasian SA. Onychomycosis in Iran: epidemiology, causative agents and clinical features. Japanese J Med Mycol. 2010;51:23-9.

49. Souza LKH, Fernandes OFL, Passos XS, Costa CR, Lemos JA, Silva MRR. Epidemiological and mycological data of onychomycosis in Goiania, Brazil. Mycoses. 2010;53:68-71.

50. Adhikari L, Gupta AD, Pal R, Singh TSK. Clinico-etiologic correlates of onychomycosis in Sikkim. Indian J Pathol Microbiol. 2009;52:194-7.

51. Godoy-Martinez P, Nunes FG, Tomimori-Yamashita J, Urrutia M, Zaror L, Silva V, et al. Onychomycosis in São Paulo, Brazil. Mycopathologia. 2009;168:111-6.

52. Hashemi SJ, Gerami M, Zibafar E, Daei M, Moazeni M, Nasrollahi A. Onychomycosis in Tehran: mycological study of 504 patients: original article. Mycoses. 2010;53:251-5.

53. Chadeganipour M, Nilipour S, Ahmadi G. Study of onychomycosis in Isfahan, Iran. Mycoses. 2010;53:153-7.

54. Das NK, Ghosh P, Das S, Bhattacharya S, Dutta RN, Sengupta SR. A study on the etiological agent and clinicomycological correlation of fingernail onychomycosis in eastern India. Indian J Dermatol 2008;53:75-9. http://www. ncbi.nlm.nih.gov/pubmed/19881992.

55. Surjushe A, Kamath R, Oberai C, Saple D, Thakre M, Dharmshale S, et al. A clinical and mycological study of onychomycosis in HIV infection. Indian $\mathrm{J}$ Dermatol Venereol Leprol. 2007;73:397-401.

56. Veer P, Patwardhan NS, Damle AS. Study of onychomycosis: prevailing fungi and pattern of infection. Indian J Med Microbiol 2007;25:53-6. http://www.ncbi.nlm.nih.gov/ pubmed/17377354.

57. Bonifaz A, Cruz-Aguilar P, Ponce RM. Onychomycosis by molds. Report of 78 cases. Eur J Dermatol. 2007;17:70-2.

58. Hilmioğlu-Polat S, Metin DY, Inci R, Dereli T, Kilinç I, Tümbay E. Non-dermatophytic molds as agents of onychomycosis in Izmir, Turkey-A prospective study. Mycopathologia. 2005;160:125-8.

59. Boukachabine K, Agoumi A. Onychomycosis in Morocco: experience of the parasitology and medical mycology laboratory from Rabat children hospital (1982-2003). Ann Biol Clin (Paris). 2005;63(6):639-42.

60. Piraccini BM, Tosti A. White superficial onychomycosis. Arch Dermatol. 2004;140:696-701.

61. Romano C, Gianni C, Difonzo EM. Retrospective study of onychomycosis in Italy: 1985-2000. Mycoses. 2005;48:42-4.

62. Bokhari MA, Hussain I, Jahangir M, Haroon TS, Aman S, Khurshid K. Onychomycosis in Lahore, Pakistan. Int J Dermatol. 1999;38:591-5.

63. Ramani R, Srinivas C, Ramani A, Kumari TGR, Shivananda PG. Molds in onychomycosis. Int $\mathrm{J}$ Dermatol. 1993;32:877-9.

64. Lim JT, Chua HC, Goh CL. Dermatophyte and non-dermatophyte onychomycosis in Singapore. Australas J Dermatol. 1992;33:159-63. 